\title{
Inverted Teaching for Improving the Teaching Performance of EFL Student Teachers at Jubail College of Education
}

\author{
Samah Zakareya ${ }^{1} \&$ Safa'a Alahmad ${ }^{1}$ \\ ${ }^{1}$ Department of English, Jubail College of Sciences and Humanities, Imam Abdulrahman Bin Faisal University, \\ Kingdom of Saudi Arabia \\ Correspondence: Samah Zakareya, Jubail College of Sciences and Humanities, Imam Abdulrahman Bin Faisal \\ University, Kingdom of Saudi Arabia.
}

Received: February 6, 2019 Accepted: March 2, 2019 Online Published: March 5, 2019

doi: 10.5539/elt.v12n4p15 URL: https://doi.org/10.5539/elt.v12n4p15

\begin{abstract}
The objective of the present study was investigating the effect of inverted teaching on EFL student teachers' teaching performance. Fifty-four EFL student teachers studying the Lesson Planning course at Jubail College of Education, Imam Abdulrahman Bin Faisal University participated in the study. They were pretested in teaching performance, then inverted teaching was implemented, finally all participants were posttested in teaching performance. Statistical analysis showed a significant improvement in the teaching performance of the participants $(t=7.6611, p<0.05)$ between the pre and post measurements in favor of the post measurement. Accordingly, the researchers concluded that inverted teaching is significantly effective in improving the teaching performance of EFL student teachers.
\end{abstract}

Keywords: EFL student teacher, inverted teaching, teaching performance

\section{Introduction}

\subsection{Problem of the Study}

The type of teaching occurring in the classrooms is very important for achieving the quality of education. This is the reason educators should always work on enhancing their teaching performance. At the College of Education in Jubail, Imam Abdulrahman Bin Faisal University, student teachers go for their Practicum only at their final semester. As a result, they are deprived of opportunities to improve their teaching performance throughout their study. Therefore, they need to practice teaching before going out to schools. An approach is needed where student teachers become active learners who have the ability to shape their professional growth (Clarke \& Hollingsworth, 2002). As faculty members at the English Department, the researchers noticed some weaknesses in the teaching performance student teachers used to show during their Practicum. Therefore, the researchers attempted to find an answer to the question: How can EFL student teachers' teaching performance be improved? In recent years, inverted teaching has been extensively used as a new model which has reshaped the long-established lecture mode (Giannakos \& Chrisochoides, 2014). Therefore, the researchers decided to investigate the use of inverted teaching as a means to develop EFL student teachers' teaching performance.

\subsection{Review of Related Literature}

Inverted teaching, sometimes called flipped teaching, is an instructional model where traditional classroom activities (lecturing) take place before class while class time is devoted to discussion, problem solving, and interaction among students (Lage, Platt, \& Treglia, 2000). The inverted classroom is an educational technique that includes two components: interactive learning activities inside the class and direct technology-based individual instruction out of the class (Bishop \& Verleger, 2013). Through this model, internet resources are provided to assist student preparation for classroom time that is then saved for applying knowledge and hands-on activities (The Queensland Government, 2012). In the inverted teaching model, learners access course material at home (Abeysekera \& Dawson, 2015) through videos that explain the information and skills (Boyer, 2013) while the classroom is turned into a workshop for interactive learning (William \& Wuensch, 2016).

Inverted teaching shifts the teacher's role away from transmitting knowledge to passive students (Montoya \& Hernández, 2016) towards guiding them to the content (Bergmann \& Sams, 2012) through active learning activities (Morrison, 2014), providing practical support (Boyer, 2013; Johnson, 2012) in the application of what 
learners have learned outside of class (Horn, 2013), and challenging them to think in a creative way (Bergmann \& Sams, 2012). In the inverted classroom, the role of teachers is no longer simply to explain knowledge, but to cultivate students' learning initiative (Zhang, 2018).

Inverted teaching also changes students' role from sitting passively and listening to the teacher's lecture (Connor, 2012) to being active learners who gather the information outside of class and apply it to new contexts during class time (Berrett, 2012). Concerning teachers' and students' attitudes towards the use of inverted teaching, Lape, et al. (2014) found that teachers enjoyed the inverted classroom environment, considered it to be lively and interactive, and liked the way it enabled them to interact with students while they built understanding of course material via problem solving. Moreover, Gross and Musselman (2018) found that students favor the learning environment of the inverted classroom.

According to Evseeva and Solozhenko (2015), the integration of inverted teaching into the educational process increases students' motivation and interest for studying foreign languages. In the inverted classroom, students become responsible for learning before class. Therefore, the instructor can spend class time working on applied active learning activities (Davis, 2013). Using the inverted model, in-class activities (e.g., lectures) are viewed by students through instructional videos before attending class, and out-of-class activities (e.g., homework problems) are done inside the classroom (McDaniel \& Caverly, 2010). According to Choi (2013), passive learning occurs outside the classroom by watching videos while classroom time is filled with activities of an in-depth conversation and mentoring.

Inverted teaching is attracting attention at various levels of education (Hoffman, 2014) as it can create a good learning environment, making up for the shortcomings of traditional teaching methods and playing an important role to stimulate students' interest in learning (Zhang, 2018). First, it enables the teacher to use classroom time more productively and innovatively (Fulton, 2012) as it frees up class time for active learning activities, rather than passive listening (Milman, 2012). Moreover, it provides more opportunities for the instructor and the learners to interact (Bergmann, Overmayer, \& Willie, 2013; Zhang, 2018) through increasing direct contact time (Pape, Sheehan, \& Worrell, 2012). Additionally, it creates a learning atmosphere that responds to students' interests (Lemmer, 2013) as learning through video makes lectures under the control of the learners as it gives them the opportunity to view and replay as they wish (Educause Learning Initiative, 2012) and as students can choose which spaces to learn in (e.g., at home, in the cafeteria, etc.) (Montoya \& Hernández, 2016). This increases their freedom (Fulton, 2012), autonomy (Driscoll \& Petty, 2014), responsibility for learning (Pape et al., 2012), collaboration (Acedo, 2013), motivation, confidence (Lemmer, 2013), and engagement (Millard, 2012). The possibility to invert space and time provides students with experiences different from those they were accustomed to in traditional academic settings (Montoya \& Hernández, 2016).

The inverted teaching model includes two components: an online component (online materials received before class) and a face-to-face component (in-class active learning activities) (Sharples et al., 2014). For the online component, the instructor either video record a lecture and upload it to students on the Internet or select relevant videos from websites such as the Khan Academy (Halili \& Zainuddin, 2015). Whether recorded or selected from the Internet, these videos should not be lengthy (Bergman \& Sams, 2012) and longer videos should be divided into parts with interactive elements (Raths, 2014). Moreover, these video lectures should be collaborative (Bergman \& Sams, 2012). This can be done through engaging students in the videos in ways such as holding a discussion about them, asking questions about them, or requiring students to take notes on them. Concerning the face-to-face component, classroom time can be used to discuss questions learners have regarding the content they received online (Rapoport, 2013). Moreover, students can use classroom time to work on activities (Wood, Galloway, Sinclair, \& Hardy, 2018) through peer collaboration (Maher, Lipford, \& Singh, 2013). Due to the benefits of inverted teaching, the researchers decided to attempt to use it to improve the teaching performance of EFL student teachers at Jubail College of Education. It was hypothesized that there would be a statistically significant difference in the teaching performance of EFL student teachers between the pre and the post measurements in favor of the post measurement.

\section{Method}

\subsection{Research Design}

The present study adopted a one-group pre-posttest quasi-experimental design. Participants were pretested in teaching performance before the experiment and posttested after it. Scores of participants on both adminstrations were statistically compared. 


\subsection{Participants}

Fifty-four EFL student teachers studying the Lesson Planning course at Jubail College of Education, Imam Abdulrahman Bin Faisal University during the 2017/2018 academic year ( $2^{\text {nd }}$ term) participated in the study. All participants were female. Students were accustomed to using Blackboard, a learning management system used to manage instructional content and track students' work.

\subsection{Measure}

To measure participants' teaching performance, the researchers designed a 39-item observation sheet. This sheet consisted of three components: planning ( 7 items), presentation ( 27 items), and evaluation (5 items). A five-point Likert scale was used in order to weigh each item in the observation sheet $(1=$ never; $2=$ rarely; $3=$ sometimes; $4=$ most of the time; $5=$ all the time). Validity of the observation sheet was confirmed when it was reviewed by three TEFL experts who made some changes in the wording of four items. Inter-rater reliability of the observation sheet was calculated using Pearson correlation coefficient and it was $(0.92)$.

\subsection{Procedures}

Procedures were executed at Jubail College of Education, Imam Abdulrahman Bin Faisal University, during the 2017/2018 academic year. First, all participants were pretested in teaching performance, then inverted teaching was implemented. Finally, all participants were posttested in teaching performance. The implementation of inverted teaching went through the following steps:

- Based on the learning outcomes and content of the Lesson Planning course, the researchers selected a number of short videos that covered all the knowledge and skills in each lecture.

- Students were oriented to inverted teaching during a 100-minute class session, where they learnt about the concept of inverted teaching, how it is used, teacher's roles, and students' roles.

- Every week, before class, students found the learning resources for the lecture on Blackboard. They had to watch the videos uploaded for the next class in order to be able to participate effectively in class.

- The researchers began each class by asking questions about the information presented in the learning resources offered to students online before class. They also answered questions posed by participants regarding the information in the videos.

- The researchers used active learning activities to engage participants in practicing what they watched in the videos. These activities included KWL charts, one-minute reflections, fishbowls, cumulative brainstorming, discussion mitten, pro-con grids, think alouds, debates, think-pair-share, and case studies.

- After class, participants reflected on the experience in a discussion forum within Blackboard. They discussed questions like "What do you think of inverted teaching?", "What can you suggest to improve this experience?" They were also allowed to search the internet for more information on the discussed topics and also to share some videos related to what they watched.

\section{Result}

In order to evaluate the difference between participants' means of scores on the pre and the post measurements of teaching performance, paired-samples t-test was employed. The t-test revealed that the difference was statistically significant as t-value was 7.6611 at the 0.05 level of significance. See the Table 1 below.

Table 1. Paired-samples t-test of participants' means of scores on the pre and the post measurements of teaching performance

\begin{tabular}{llllll}
\hline & \multicolumn{2}{l}{ Paired Differences } & $\mathrm{t}$ & $\mathrm{df}$ & Probability \\
\cline { 1 - 3 } Posttest-Pretest & Mean & Std. Error Mean & & & \\
\cline { 2 - 5 } & 31.65 & 4.131 & 7.661 & 53 & Significant \\
\hline
\end{tabular}

\section{Discussion}

The purpose of the present study was to investigate the effect of inverted teaching on EFL student teachers' teaching performance. Employing a paired-samples t-test, statistical analysis showed a significant difference in favor of the post measurement $(\mathrm{t}=7.6611, \mathrm{p}<0.05)$. Therefore, it can be said that inverted teaching improves EFL student teachers' teaching performance. This result goes along with the result found by Hussain, Ahmad, Saeed, 
and Khan (2015) who studied the effect of the inverted learning approach on prospective teachers' pedagogical skills. They found that the inverted model improved prospective teachers' instructional planning, presentation, classroom management, and assessment skills.

A possible justification for the result of the present study may be that participants watched and shared videos related to preparing, presenting, and evaluating English lessons. This might have allowed them, as student teachers, to imitate or follow the good teaching practices they watched in the videos. Moreover, they could control the pace as well as the number of views of the videos through replaying and pausing which provided them with more opportunities to benefit pedagogically from these videos. This explanation agrees with the results of some studies which found that watching videos of model teachers can improve teaching skills (e.g., Matthews, 2007).

Inverted teaching replaces in-class lectures with active student engagement in experiential learning activities, while the main content is provided through videos offered before class (Foster \& Stagl, 2018). Therefore, another possible reason for this result is the effect of active learning activities where student teachers practiced what they watched in the videos during class time. These activities helped to consolidate the knowledge and skills that student teachers received in a theoretical way through the videos. This explanation is congruent with the result of the study of Virtanen, Niemi, and Nevgi (2017) who found that active learning activities enhanced student teachers' professional competencies.

A final explanation for this study's result is the effect of the discussions and reflections student teachers practiced on Blackboard. Through, these discussions they could express their views towards different teaching issues. This might have helped them identify and explore different effective teaching practices, which were then reflected in their teaching performance. This explanation is supported by the results of some studies which found that discussion and reflection improve teaching performance (e.g., Kumari, \& Naik, 2015; Ufuk, 2017).

\section{Conclusion}

The result reached in the present study led the researchers to conclude that the inverted teaching could significantly improve the teaching performance of EFL student teachers. This teaching model can be adopted in other courses or used by other teachers at Imam Abdulrahman Bin Faisal University.

\section{Recommendations and Suggestions for Further Research}

In light of the result of the present study, the researchers recommend: 1) devoting class time to practical activities, rather than theoretical lectures, 2) using inverted teaching for enhancing the listening comprehension of EFL learners, 3) providing EFL student teachers adequate opportunities to practice teaching before going to practicum, and 4) encouraging them to use videos available on the internet of good teaching practices. Moreover, the researchers suggest conducting research studies investigating: 1) the effect of inverted teaching on EFL student teachers' teaching self-efficacy and 2) EFL student teachers' attitude towards using of inverted teaching.

\section{References}

Abeysekera, L., \& Dawson, P. (2015). Motivation \& cognitive load in the flipped classroom: Definition, rationale, \& a call for research. Higher Education Research \& Development, 34(1), 1-14. https://doi.org/10.1080/07294360.2014.934336

Acedo, M. (2013). Ten pros \& cons of a flipped classroom. Retrieved March 13, 2015, from http://www.teachthought.com/uncategorized/10-pros-cons-flipped-classroom/

Bergmann, J., Overmyer, J., \& Wilie, B. (2013, July 9). The flipped class: What it is \& what it is not. The Daily Riff. Retrieved July 11, 2015, from http://www.thedailyriff.com/articles/the-flipped-class-conversation689.php

Bergmann, J., \& Sams, A. (2012). Flip your classroom: Reach every student in every class every day. Washington, DC: International Society for Technology in Education. http://dx.doi.org/10.1111/teth.12165

Berrett, D. (2012). How flipping the classroom can improve the traditional lecture. Education Digest, 78(1), $36-41$.

Bishop, J., \& Vergeler, M. (2013). The flipped classroom: A survey of the research. Paper presented at the 120th ASEE Annual Conference \& Exposition. Retrieved August 27, 2013, from http://www.asee.org/public/conferences/20/ papers/6219/view

Boyer, A. (2013). The flipped classroom: Catering for difference. Teacher Learning Network, 20(1), 28-29.

Choi, E. (2013). Applying inverted classroom to software engineering education. International Journal of 
e-Education, e-Business, e-Management \& e-Learning, 3(2), 121-125. https://doi.org/10.7763/IJEEEE.2013. V3.205

Clarke, D., \& Hollingsworth, H. (2002). Elaborating a model of teacher professional growth. Teaching \& Teacher Education, 18(8), 947-967.

Connor, K. (2012). Goodbye, Podium: An engineering course puts theory into practice. Chronicle of Higher Education, 59(6), B30-B31.

Davis, C. (2013). Flipped or Inverted Learning: Strategies for Course Design. In E. Smyth, \& J. Volker (Eds.), Enhancing instruction with visual media: Using video \& lecture capture (pp. 241-265). Hershey, PA: IGI Global. https://doi.org/10.4018/978-1-4666-3962-1.ch017

Driscoll, T., \& Petty, K. (2014). Student-driven education with flipped learning \& 20-time. In L. Kyei-Blankson, \& E. Ntuli (Eds.), Practical applications \& experiences in K-20 blended learning environments (pp. 120-136). Hershey, PA: Information Science Reference.

Educause Learning Initiative. (2012). Seven things you should know about flipped classrooms. Retrieved August 23, 2015, from https://net.educause.edu/ir/library/pdf/ELI7081.pdf

Evseeva, A., \& Solozhenko, A. (2015). Use of flipped classroom technology in language learning. Procedia--Social \& Behavioral Sciences, 206, 205-209. https://dx.doi.org/10.1016/j.sbspro.2015.10.006

Foster, G., \& Stagl, S. (2018). Design, implementation, \& evaluation of an inverted (flipped) classroom model economics for sustainable education course. Journal of Cleaner Production, 183(10), 1323-1336. https://doi.org/10.1016/j.jclepro.2018.02.177

Fulton, K. (2012). Upside down \& inside out: Flip your classroom to improve student learning. Learning \& Leading with Technology, 39(8), 12-17.

Giannakos, M., \& Chrisochoides, N. (2014). Challenges \& perspectives in an undergraduate flipped classroom experience: Looking through the lens of learning analytics. Proceedings of Frontiers in Education Conference (pp. 1-5). Madrid: IEEE. https://doi.org/10.1109/FIE.2014.7044449

Gross, S., \& Musselman, E. (2018). Implementation of an inverted classroom in structural design courses. Journal of Professional Issues in Engineering Education \& Practice, 144(3).

Halili, S., \& Zainuddin, Z. (2015). Flipping the classroom: What we know \& what we don't. The Online Journal of Distance Education \& e-Learning, 3(1), 15-22.

Hoffman, E. (2014). Beyond the flipped classroom: Redesigning a research methods course for E3 instruction. Contemporary Issues in Education Research, 7(1), 51-62.

Horn, M. (2013). The Transformational potential of flipped classrooms: Different strokes for different folks. Education Next, 13(3), 78-79.

Hussain, S., Ahmad, N., Saeed, S., \& Khan, F. (2015). Effects of flip learning approach on prospective teachers' pedagogical skills. The Dialogue, 10(3), 326-337.

Johnson, G. (2012). Students, please turn to YouTube for your assignment. Education Canada, 52(5), 16-18.

Kumari, V., \& Naik, S. (2015). Effect of reflective teaching training \& teaching aptitude on teaching skills among elementary teacher trainees. Journal on Educational Psychology, 9(3), 11-23.

Lage, M., Platt, G., \& Treglia, M. (2000). Inverting the classroom: A gateway to creating an inclusive learning environment. Journal of Economic Education, 31(1), 30-43. https://doi.org/10.1080/00220480009596759

Lape, N., Levy, R., Yong, D., Haushalter, K., Eddy, R. \& Hankel, N. (2014). Probing the inverted classroom: A controlled study of teaching \& learning outcomes in undergraduate engineering \& mathematics. $121^{s t} A S E E$ Annual Conference \& Exposition, June 15-18, 2014, Indianapolis, IN.

Lemmer, C. (2013). A view from the flip side: Using the inverted classroom to enhance the legal information literacy of the international LL.M. student. Law Library Journal, 105(4), 461-491.

Maher, M., Lipford, H., \& Singh, V. (2013). Flipped classroom strategies using online videos. Technical Report, Center for Education Innovation, University of North Carolina, Charlotte. Retrieved May 15, 2015, from http://cei.uncc.edu/sites/default/files/CEI\%20Tech\%20Report\%203.pdf

Matthews, J. (2007). Using videoconferencing to enhance the teaching \& learning of the target language. Retrieved April 17, 2018 from http://www.leonardo-lets.net/ict/common/download/JacquelineMatthews.pdf 
McDaniel, S., \& Caverly, D. (2010). Techtalk: The community of inquiry model for an inverted developmental math classroom. Journal of Developmental Education, 34(2), 40-41.

Millard, E. (2012). Five reasons flipped classrooms work: Turning lectures into homework to boost student engagement \& increase technology-fueled creativity. University Business, 15(11), $26-29$.

Milman, N. (2012). The flipped classroom strategy: What is it \& how can it best be used? Distance Learning, 9(3), 85-87.

Montoya, M. \& Hernández, D. (2016). Inverted learning environments with technology, innovation \& flexibility: Student experiences \& meanings. Journal of Information Technology Research, 9(1), 18-33. https://doi.org/10.4018/JITR.2016010102

Morrison, C. (2014). From sage on the stage to guide on the side: A good start. International Journal for the Scholarship of Teaching \& Learning, 8(1). https://doi.org/10.20429/ijsotl.2014.080104

Pape, L., Sheehan, T., \& Worrell, C. (2012). How to do more with less: Lessons from online learning. Learning \& Leading with Technology, 39(6), 18-22.

Rapoport, N. (2013). Rethinking U.S. legal education: No more 'same old, same old'. Connecticut Law Review, 45(4), 1409-1429.

Raths, D. (2014). Nine video tips for a better flipped classroom. Education Digest, 79(6), 15-21.

Sharples, M., Adams, A., Ferguson, R., Gaved, M., McAndrew, P., Rienties, B., ... Whitelock, D. (2014). Innovating pedagogy 2014: Open University innovation report 3. Milton Keynes: The Open University.

The Queensland Government. (2012). The flipped classroom: Classroom connections. Retrieved June 19, 2015, from https://classroomconnections.eq.edu.au/topics/Pages/2012/november/flipped-classroom.aspx

Ufuk, T. (2017). Investigation of reflective teaching practice effect on training development skills of the pre-service teachers. Journal of Education \& Training Studies, 5(6), 232-239. https://doi.org/10.11114/ jets.v5i6.2348

Virtanen, P., Niemi, H., \& Nevgi, A. (2017). Active learning \& self-regulation enhance student teachers' professional competencies. Australian Journal of Teacher Education, 42(12), 1-20. https://doi.org/10. 14221/ajte.2017v42n12.1

Williams, S., \& Wuensch, K. (2016). Flipping quantitative classes: A triple win. Decision Sciences: Journal of Innovative Education, 14(1), 67-89. https://doi.org/10.1111/dsji.12088

Wood, A., Galloway, R., Sinclair, C. \& Hardy, J. (2018). Teacher-student discourse in active learning lectures: Case studies from undergraduate physics. Teaching in Higher Education, 23, 1-17. https://doi.org/10.1080/ 13562517.2017.1421630

Zhang, H. (2018). Application of inverted classroom in college English teaching. $3^{\text {rd }}$ International Conference on Society Science \& Economics Development. January 27-28, 2018, Nanjing, China. https://doi.org/10. $12783 / \mathrm{dtem} / \mathrm{icssed} 2018 / 20205$

\section{Copyrights}

Copyright for this article is retained by the author(s), with first publication rights granted to the journal.

This is an open-access article distributed under the terms and conditions of the Creative Commons Attribution license (http://creativecommons.org/licenses/by/4.0/). 